\title{
The Implementation of Public Information Disclosure Through People's Online Complaints Integrated on Information and Services Center in Medan State University, Indonesia
}

\author{
M. Surip ${ }^{1}$, Hendra Kurnia Pulungan ${ }^{1}$ \\ State University of Medan (Unimed), Indonesia \\ achmadyuhdi@gmail.com
}

\begin{abstract}
The People's Aspiration Service and the People's Online Complaints (LAPOR) and Integrated Information and Service Center are the two flagship programs of the Medan State University Information and Documentation Management Officer (PPID). These two programs are an effort to follow up on Law Number 14 of 2008 concerning Public Information Openness. The program is also an effort of Unimed in supporting the creation of Good Governance especially in the field of higher education services. This study aims to find out how the implementation of LAPOR programs on public information disclosure in Unimed. This type of research is descriptive qualitative. The focus of this research is implementation, access, mechanisms and constraints. Policy implementation is implemented to achieve the objectives of an institution. At the policy implementation stage, the policies that have been made or determined will be implemented, however, the implementation phase of this policy is the most severe stage, this is because in implementing or implementing a policy will certainly experience various kinds of problems in the field. Public information disclosure is regulated in Law No. 14 of 2008 concerning Public Information Openness (UU KIP).
\end{abstract}

Keywords: information; public information disclosure

\section{Introduction}

Law Number 14 of 2008 concerning Public Information Openness is a legal product issued by the government to regulate public information disclosure in state institutions and non-governmental organizations whose part or all of the funds are sourced from public funds, both the State Budget and Regional Revenues and Expenditures. , community contributions, as well as foreign sources. The Law on Public Information Openness requires governments and public bodies to build and develop information and documentation systems to be widely accessible to the public. The right to access information is the right to transparency in the management of funds / public resources, the right to information managed by public bodies, and the right to information to determine the performance of officials in carrying out government functions.

Since the enactment of Law No. 14 of 2008, various research results / case studies regarding the form of implementation in realizing public information disclosure have been widely publicized. It's just that the publication is a study conducted by the district / city 
government. One of them is Pratikno, et al (2012), who conducted a study on the implementation of public information disclosure in various regions, namely East Java, West Papua, Aceh and DKI Jakarta. The study tried to try to uncover the level of achievement in each region and the obstacles and opportunities for improvement. This study found high variations in terms of achievement, both institutional achievements through the installation of Regional Information Commissions and Information and Documentation Management Officials, as well as substantive achievements directly related to the availability of public information, means to access and access levels. These achievement variations are influenced by various factors, ranging from the limited socialization related to public information disclosure, the limited capacity of implementers, to systematic resistance to reject the implementation.

After the enactment of the Act, Kemenristekdikti also issued Minister of Research, Technology and Higher Education Regulation Number 59 of 2016 concerning Public Services in the Ministry of Research, Technology and Higher Education. In response to the Minister of Research, Technology and Higher Education Regulation No. 59 of 2016 mentioned above, Unimed as a state higher education institution strongly supports the creation of Good Governance, especially in the field of Higher Education Services. Aware of the demands of the flow of reform to be transparent and accountable in carrying out various tasks in carrying out the Tri Dharma of Higher Education, Unimed formed the Information and Documentation Management Officer (PPID) from the implementation, management and implementation of tasks in the field of higher education to be accessible to stakeholders.

The Unimed PPID is responsible for the field of public information services which includes the storage, documentation, provision and service of public information. PPID is responsible for coordinating the storage and documentation of all public information in the Public Agency (Unimed). In the framework of responsibility, the PPID is in charge of coordinating the collection of all physical information physically from each unit / work channel which includes: a) Information that must be provided and announced periodically, b) information that must be available at all times, and c) other open information asked by the applicant for public information.

The implementation of the Minister of Research, Technology and Higher Education Regulation Number 59 of 2016 concerning Public Service at the Ministry of Research, Technology and Higher Education at Medan State University until 2017 has been responded quickly enough, and has been developed in stages with the establishment of PPID in early 2018 in providing information services to the public. In its implementation, PPID formed two excellent service programs, namely the People's Online Aspiration and Complaints Service (LAPOR) and the Integrated Information and Services Center (PINTU). These two service programs are expected to provide fast and accurate information to the public. This research will then describe how to implement the People's Online Aspiration and Complaints Service (LAPOR) and the Integrated Information and Services Center (PINTU) as a space in disseminating information about Unimed to the public. In addition, this study also describes various forms of constraints faced in the implementation of the public information service program.

\section{Review of Literature}

\section{II.1 Definition of Public Information}


Public information disclosure in Unimed basically refers to Law No. 14 of 2008, concerning Public Information Openness. The law essentially gives an obligation to every Public Agency to open access for every public information applicant to obtain public information. Until now, the implementation of public services in Unimed has run well following the principles of information disclosure as referred to in the Act. In addition to Law No. 14 of 2008, Law Number 25 of 2009 concerning Public Services, specifically Article 4 letter $\mathrm{h}$ provides limitations on the principle of transparency in public services, among others, explained that each service recipient can easily access and obtain information about the desired service.

Furthermore, according to BAPPENAS the principle of openness has at least 7 (seven) minimum indicators, including: 1) Availability of adequate information in each process of formulating and implementing public services; 2) Free service information is obtained by anyone; 3) Information provided on time in the framework of evaluation and monitoring; 4) Availability of good information facilities and infrastructure; 5) There is access for the public to information that is readily available; 6) Information easily accessible; 7) Open attitude of government officials in conveying information.

Furthermore, in the aforementioned Law, specifically Article 1 Number (1) states that: public service is an activity or series of activities in order to fulfill service needs in accordance with the laws and regulations for every citizen and population on goods, services and / or services administration provided by public service providers. The concept of openness in service refers to a situation where all aspects of the service delivery process are open and can be accessed easily by service users and stakeholders in need. If all aspects of service delivery, especially those relating to rights and obligations between service providers / service providers and service users, can be accessed easily and publicly published so that they are easily understood by the public, the practice has a high level of openness, such as: requirements, time, costs, service flow, complaints mechanism and so on. Conversely, when all or part of the service aspect is not open and difficult to access by service users and stakeholders, the service delivery has a low level of openness, or in other words does not meet the rules of openness (Suharno, 2006: 18). Openness has an important role in the administration of government / public bodies, also in public services, so that academics in universities must be given the widest access to the process of organizing public services.

Agus Dwiyanto (2005: 194) said that the value of openness culture can have complex impacts in the administration of government and public services, including: 1) Because openness is one of the main principles, so it will have a significant role for the realization of good governance as a vision to be achieved in the Bureaucratic Reform program. 2) Openness can also have an impact on increasing participation in public services, because the public will actively participate if given the broadest access and information and easily recognize the implementation of public service activities, as well as their rights and obligations as service users. 3) Openness also has a close relationship with public accountability, because the public will be willing and able to evaluate public service policies, if the public given the widest and easiest opportunity to access and obtain information on policies and actions carried out by the Bureaucracy as providers / service providers 4) Openness will also provide a very large contribution to law enforcement efforts and eradication of KKN. Because the public can become apathetic in addressing law enforcement efforts and eradicating corruption, collusion and nepotism as a result of law enforcement officers who are often not transparent in the process of law enforcement and selective cutting practices. 
Public information services in universities are regulated in the Minister of Research, Technology and Higher Education Regulation Number 75 in 2016 concerning Public Information Services in the Ministry of Research, Technology and Higher Education Environment. In the Permenristekdikti, the intended public information is information produced, stored, managed, sent and / or received by the Information and Documentation Management Officer (PPID) relating to the administration and administration of the state, as well as other information relating to the public interest. Ministry PPID and PTN PPID Legal Entity as referred to in Article 3 paragraph (1) letter b and Article 4 paragraph (1) letter b have the duties and authority: (a) to collect, provide, store, document and secure information; (b) provide fast, precise and simple public information services in accordance with the provisions of the legislation; (c) establish operational procedures for the dissemination of Public Information; (d) establish information that is excluded based on consequence tests; (e) determine the classification of public information and / or change it; (f) determine the excluded public information that has expired exceptions as public information that can be accessed; (g) determine written consideration for every policy taken to fulfill each person's right to Public Information; (h) coordinate with the Implementing PPID; (i) carry out guidance on the Implementing PPID; and (j) evaluating the Implementing PPID.

\section{II.2 People's Online Complaint Aspiration Service (LAPOR) and Integrated Information and Service Center (PINTU) in Unimed}

In connection with the duties and authorities of PPID as referred to in the paragraph above, Unimed formed the People's Online Complaint Aspiration Service Team (LAPOR) in the Medan State University Environment through the Chancellor's Decree Medan State University Number 04 / UN33.KEP / 2018. The LAPOR team is then tasked to serve the complaints of the Unimed academic community in terms of research, service, human resources, and students, as well as requests for information and collaboration through the Integrated Information and Services Center (PINTU). As for the service mechanisms applied by the Integrated Information and Services Center are: (1) information applicants come directly to the DOOR office or submit an application online, (2) the applicant completes a complaint form or requests information or downloads and fills out the form through www.unimed.ac.id, (3) an individual applicant must show an original KTP / KTM along with the photocopy, while if the social organization must show the official legality of the organization from the Decree of the Minister of Law and Human Rights or send the form to PINTU via email humas@unimed.ac.id. (4) DOOR officers submit proof of receipt of complaints and information, (5) the applicant waits for an answer process for approval or disapproval of the application, and (6) Complaint settlement has $10+7$ days to answer complaints and information in accordance with Law No. 14 of 2008.

\section{Research Methodology}

The research method used to answer this research is a descriptive research method with a qualitative approach referring to the statements of Narbuko and Achmadi (2004: 44) and the statements of Taylor and Bogdan in Danim (2002: 41). While the data used in this study is primary data and secondary data refer to Danim (2002: 140,130). Primary Data, which is data directly obtained from the field obtained through observation and interviews. Secondary data in this study is documentation of relevant literature with research titles such as books, articles, papers, regulations, organizational structure, schedule, time, implementing 
instructions, technical instructions and others that have relevance to the problem under study. Data collection techniques Data collection of this study uses direct observation method, namely at the Office of Information and Integrated Services, Medan State University. Observations are carried out directly in a place that is the object of research, while the object observed is the activity of the academic community in registering complaints and the implementing team in carrying out the task. Interviews were conducted with two models, namely general interview instructions and open standard interviews referring to Patton's statement (in Moleong, 2002: 197). While data analysis in qualitative research takes place interactively, where in each case hapan activities do not run independently as argued by Miles (2007: 15-19). Test the credibility of the data or the confidence in the data from this study, among others, was carried out by extension of observation, improvement of provisions in research, triangulation, discussion with peers and member check. The use of this test is intended to get more in-depth data about research subjects (Sugiono, 2008: 270).

\section{Discussion}

Policy implementation is implemented to achieve the objectives of an institution. At the policy implementation stage, the policies that have been made or determined will be implemented, however, the implementation phase of this policy is the most severe stage, this is because in implementing or implementing a policy will certainly experience various kinds of problems in the field. Public information disclosure is regulated in Law No. 14 of 2008 concerning Public Information Openness (UU KIP). After the enactment of the Act, Kemenristekdikti also issued Minister of Research, Technology and Higher Education Regulation Number 59 of 2016 concerning Public Services in the Ministry of Research, Technology and Higher Education. Following up on the Minister of Research, Technology and Higher Education Regulation No. 59 of 2016 mentioned above, Unimed as a state higher education institution strongly supports the creation of Good Governance, especially in the field of Higher Education Services.

Aware of the demands of the flow of reform to be transparent and accountable in carrying out various tasks in carrying out the Tri Dharma of Higher Education, Unimed formed the Information and Documentation Management Officer (PPID) from the implementation, management and implementation of tasks in the field of higher education to be accessible to stakeholders. The Unimed PPID is responsible for the field of public information services which includes the storage, documentation, provision and service of public information. PPID is responsible for coordinating the storage and documentation of all public information in the Public Agency (Unimed). In the framework of responsibility, the PPID is in charge of coordinating the collection of all physical information physically from each unit / work channel which includes: a) Information that must be provided and announced periodically, b) information that must be available at all times, and c) other open information requested by the public information applicant. Implementation of the Minister of Research, Technology and Higher Education Regulation No. 59 of 2016 concerning Public Service at the Ministry of Research, Technology and Higher Education at Medan State University until 2017 has been responded quickly enough, and has been developed in stages with the formation of PPID in early 2018 in providing information services to the public. In its implementation, PPID formed two excellent service programs, namely the People's Online Aspiration and Complaints Service (LAPOR) and the Integrated Information and Services Center (PINTU). These two service programs are expected to provide fast and accurate information to the 
public. Based on the existing regulations, Unimed strives to carry out its obligations to support the creation of Good Governance, especially in the field of Higher Education Services by creating a portal for Online People's Aspirations and Complaints Services (LAPOR ) and Integrated Information and Service Centers (PINTU) to support and facilitate Unimed in managing Public Information disclosure. To see how the implementation process / Implementation of Public Information Openness through the Online People's Aspirations and Complaints Service (LAPOR) and Integrated Information and Services Center (PINTU) in Unimed can be seen from the aspect of Policy Accuracy, Implementation Accuracy, Target Accuracy, Environmental Accuracy, Process Accuracy as explained in the following sections: 1. Policy Accuracy

Policy accuracy looks at how a policy can solve problems and achieve the desired goals. Accuracy The policy of implementing public information disclosure through the People's Online Aspirations and Complaints Service (LAPOR) and the Integrated Information and Services Center (PINTU) is in accordance with the objectives of the Public Information Disclosure contained in the Public Information Openness Act No.14 of 2008, where the portal of the Online People's Aspirations and Complaints Service (LAPOR) and Integrated Information and Services Center (PINTU) facilitates and encourages the public to access public information. In addition, the implementation of public information disclosure through the People's Online Aspiration and Complaints Service (LAPOR) and the Integrated Information and Services Center (DOOR) is indeed a rarity h right to do by Unimed, seeing that the community is now in an era of technological development, everything can be accessed anytime and anywhere they are, easily, quickly, and at a low cost.

\section{Accuracy of Implementation}

Based on Law No. 14 of 2008 concerning Public Information Openness, to realize fast, precise and simple services, every public body must form an Information and Documentation Management Officer (PPID). Based on the results of the research and interviews with informants, all implementing actors have done work in accordance with the duties and functions they have, they are very understanding and understanding what they have to do, moreover the actors in this case are PPIDs, have been selected and determined with competence in field of public information management.

\section{Accuracy of the implementation}

Public information disclosure through the People's Online Complaints and Complaints Service (LAPOR) and the Integrated Information and Services Center (PINTU) in Unimed can be seen from the accuracy of the target, the accuracy of this target involves three things, namely: a. First, the accuracy of the target is in accordance with what is planned or written in the implementation instructions or regulations, by choosing the People's Online Aspiration and Complaint Service (LAPOR) and the Integrated Information and Service Center (PINTU) as an information expansion medium that can be accessed widely and easily and quickly, then the first target accuracy requirement has been met by Unimed.b. Second, the range of targets, whether this policy has a wide range as planned. Public Information Openness through the People's Online Aspirations and Complaints Service (LAPOR) and the Integrated Information and Services Center (PINTU) has reached all levels of society, can be accessed by anyone and anywhere they are. C. Third, the nature of policy is new or renewed.

\section{Conclusion}


Related to the Public Information Disclosure Act in Indonesia, Kemenristekdikti also issued Minister of Research, Technology and Higher Education Regulation Number 59 of 2016 concerning Public Services in the Ministry of Research, Technology and Higher Education. Following up on the Minister of Research, Technology and Higher Education Regulation No. 59 of 2016 mentioned above, Unimed as a state higher education institution strongly supports the creation of Good Governance, especially in the field of Higher Education Services. Aware of the demands of the flow of reform to be transparent and accountable in carrying out various tasks in carrying out the Tri Dharma of Higher Education, Unimed formed the Information and Documentation Management Officer (PPID) from the implementation, management and implementation of tasks in the field of higher education so that it can be accessed by stakeholders.

\section{References}

Agus Dwiyanto. (2005). Mewujudkan Good Governance Melalui Pelayanan Publik. Yogyakarta: Pustaka Pelajar.

Achmadi dan Narbuko (2004). Metode Penelitian. Jakarta: Bumi Aksara.

Danim, Sudarwan. (2002). Menjadi Peneliti Kualitatif; Ancangan Metodologi, Presentasi, dan Publikasi Hasil Penelitian untuk Mahasiswa dan Peneliti La Bidan Ilmu Ilmu Sosial, Pendidikan, dan Humaniora. Bandung: CV. Pustaka Setia.

Moleong, Lexy. (2002). Metodologi Penelitian Kualitatif. Bandung: PT. remaja Rosdakarya. Pratikno, dkk. (2012). Kajian Implementasi Keterbukaan Informasi Publik dalam Pemerintahan Lokal Pasca Undang-Undang Nomor 14 Tahun 2008. Cetakan Pertama. Yogyakarta: Yayasan Tifa dan Fisipol UGM Yogyakarta.

Peraturan Menteri Riset, Teknologi dan Pendidikan Tinggi Nomor 59 tahun 2016 tentang Pelayanan Publik di Kementerian Riset, Teknologi dan Pendidikan Tinggi

Suharno. (2013). Dasar-dasar Kebijakan Publik. Yogyakarta: Ombak.

Sugiyono, (2008). Metode Penelitian Kunatitatif Kualitatif dan R\&D. Bandung Alfabeta. Undang-Undang RI Nomor 14 Tahun 2008 Tentang Keterbukaan Informasi Publik Undang Undang Nomor 25 Tahun 2009 tentang Pelayanan Publik. 